\title{
Assessment of Magetan regency's road performance based on pavement and off pavement components
}

\author{
Joko Tri Haryanta ${ }^{1, *}$, Mamok Suprapto ${ }^{2}$, and Syafi ' $i^{2}$ \\ ${ }^{1}$ Student, Master Program of Civil Engineering, Sebelas Maret University, Indonesia \\ ${ }^{2}$ Lecturer, Master Program of Civil Engineering, Sebelas Maret University, Indonesia
}

\begin{abstract}
Roads are made up of both pavement and off pavement components. In many cases, only road pavement is subjected to maintenance, leaving out accessory road components even though these components also contribute to overall road performance. Hence, the assessment of both road pavement and road components is vitally important in keeping roads safe and enhancing their overall performance. This study was conducted to know the performance of a select road as well as relevant handling recommendations. The research was carried out on 16 road sections of Magetan Regency, East Java Province with a total length of $85.60 \mathrm{~km}$. The Kabupaten Road Management System (KRMS) Software was used in gathering precise road performance information. Weighting of road components was done using AHP (Analytical Hierarchy Process) while priority handling was determined using Analysis Network Process (ANP) with Super Decision software. A camera was used for the observation of both road and off pavement conditions. From research results after analyzing 16 Straight Line Diagrams, all road segments were in good condition. However, routine maintenance recommendations have been provided after a 16 Strip Map Diagram analysis of road segments. The first priority is Genengan-Lembeyan road segment followed by the Tamanarum-Lembeyan road.
\end{abstract}

\section{Introduction}

Road plays a fundamental role in a nation's economic and social well-being. A common problem, however, is that roads deteriorate in quality after extended periods of use. This can lead to longer journey durations, increased accidents and a number of other untold road problems for users. Thus, routine and sustainable road maintenance activities are always needed to keep roads motorable and safe for users. This has necessitated the study of KRMS needs which helps to determine the type and extent of road damage as well as proffer best measures to handle the damages.

\footnotetext{
* Corresponding author: jokotrio_o@yahoo.co.id
} 
The purpose of this research is to determine road performance status after analysis using KRMS software and also to present necessary recommendations for road handling based on road performance results.

\section{Literature review}

\subsection{Functional conditions of roads}

Functional conditions of roads are key in determining road performance. These conditions are perceived by road users and include roughness, rut depth, and skid resistance. Assessment of functional conditions of roads can be done by physical evaluation through field evaluation and observation. Results are then documented for visual assessment. Suwardo and Sugiharto [1] argue that Roughness Index (RI) is one of many factors with great influence on comfort of drivers when on the road. Additionally, Suherman [2] posits that road roughness directly affects diver comfort. Hence the need to conduct periodical road inspection for better road performance.

\subsection{Road performance}

Road performance is the relative function and ability of road pavements to optimally meet traffic demands within a certain period. To determine the state of road conditions, the International Roughness Index (IRI) method [3] and its calibrated value [4] can be used.

In addition to determining the IRI value, road performance can be further evaluated by taking account of the Pavement Condition Index (PCI), Pavement Condition Distress Index (PCIDistress), Pavement Condition Roughness Index (PCIRoughness), Pavement Condition Structural Capacity Index (PCIStructure), and Pavement Condition Skid Resistance Index (PCISkid). All of these road determinants will help in eventually determining the Overall Pavement Condition Index [5]. Thus, road performance can be determined using the values of IRI, PCI and SDI [6] as well as the combination of the three methods [7].

To investigate road performance based on the functional and structural conditions of roads, the method used by Bina Marga and AASHTO 1993 can be adopted. With this method, the score of Structural Number (SN) can be obtained. Additionally, the comparison of SNeffective/SNfuture gives the score of Structural Condition Index (SCI) [8]. While the aforementioned methods are helpful in determining key road performance metrics, a new method using a special software - Kabupaten Road Management System (KRMS) - can also be used [9]. The KRMS software utilizes data collected after visual assessment of the extent of road damage to give a number of informative results including the Straight-Line Diagram, Diagram Map Report, Routine Maintenance Program Report, Primary Work Program Report, Road Condition Projection Report, Package Report, and Statistical Report.

\section{Research method and data collection technique}

This research was conducted in Magetan Regency, East Java Province. The road sections analyzed in this research were those in Magetan Regency with the total length of $85.60 \mathrm{~km}$ as shown in Table 1. 
Table 1. Name of road section location.

\begin{tabular}{|l|l|l|l|l|}
\hline No. & Name of Road Section & $\begin{array}{l}\text { Sub-district } \\
\text { Traversed }\end{array}$ & $\begin{array}{l}\text { Length } \\
(\mathbf{k m})\end{array}$ & $\begin{array}{l}\text { Type of } \\
\text { pavement }\end{array}$ \\
\hline 1. & Takeran-Mardigondo & Takeran & 5,50 & Asphalt \\
\hline 2. & Maospati-Karangsono & Maospati-Barat & 4,50 & Asphalt \\
\hline 3. & Tebon-Karangmojo & Barat-Kartoharjo & 3,60 & Asphalt \\
\hline 4. & Tebon-Batur & Barat & 4,00 & Asphalt \\
\hline 5. & Karangsono-Teguhan & Barat-Maospati & 5,50 & Asphalt \\
\hline 6. & Purwodadi-Grabahan & Barat-Karangrejo & 2,30 & Asphalt \\
\hline 7. & Genengan-Lembeyan & Kawedanan-Lembeyan & 10,30 & Asphalt \\
\hline 8. & Tamanarum-Lembeyan & Parang-Lembeyan & 7,40 & Asphalt \\
\hline 9. & Parang-Turus & Parang-Poncol & 11,60 & Asphalt \\
\hline 10. & Ringinagung-Bangsri & Ngariboyo & 1,10 & Asphalt \\
\hline 11. & Tulung-Kenongomulya & Kawedanan-Takeran & 5,50 & Asphalt \\
\hline 12. & Panekan-Jabung & Panekan & 4,40 & Asphalt \\
\hline 13. & Tinap-Jongke & Sukomoro-Karas & 5,70 & Asphalt \\
\hline 14. & Takeran-Kenongomulya & Takeran & 3,40 & Asphalt \\
\hline 15. & Pupus-Tapen & Lembeyan & 3,70 & Asphalt \\
\hline 16. & Pupus-Semen & Lembeyan-Takeran & 7,10 & Asphalt \\
\hline TOTAL & & 85,60 & \\
\hline
\end{tabular}
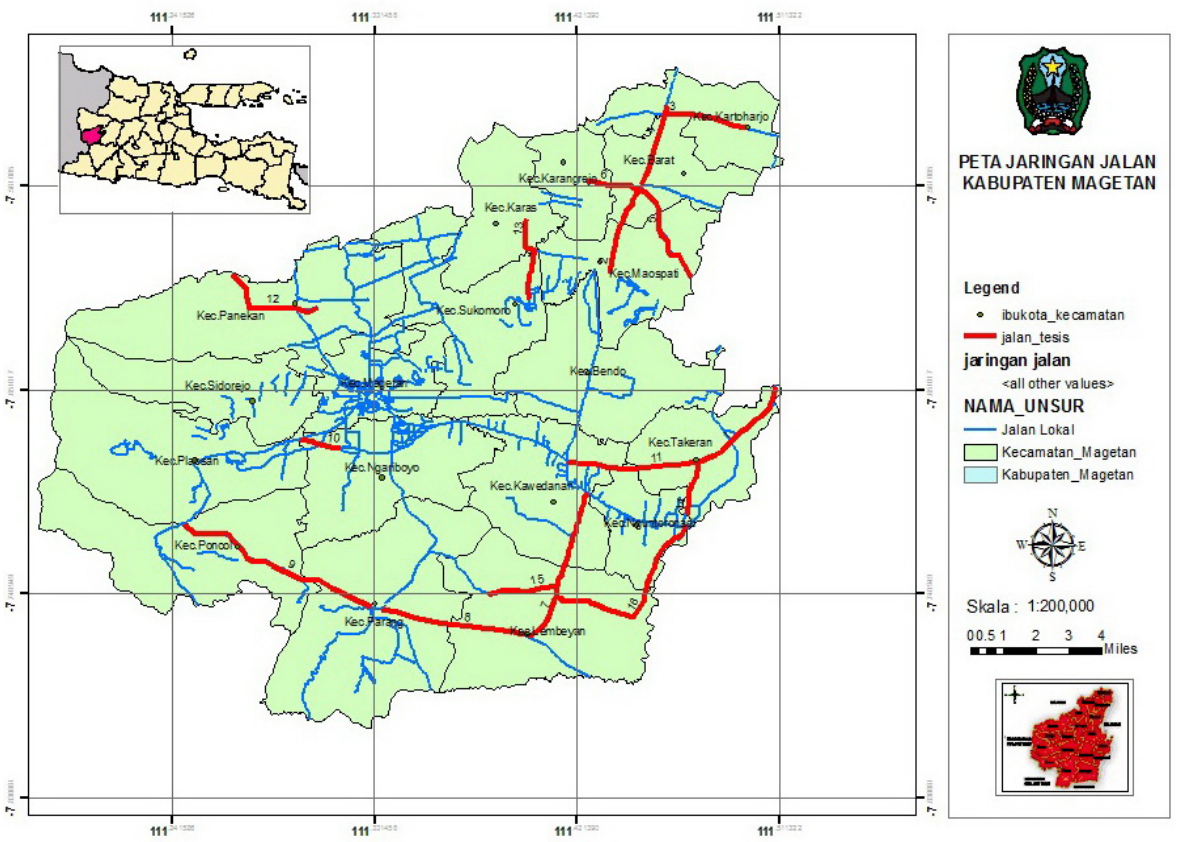

Fig. 1. Map of research location.

Data on road and road component damages collected in the survey were in a video format. The visual assessment of the video was afterwards done to determine the damages of the road and its complementary facilities. For more extensive results, secondary data were obtained from the Office of Public Works and Development Planning Agency at SubNational Level of Magetan Regency. These data included Magetan Regency administrative 
map, road section map, and Average Daily Traffic (ADT) data. The full methodology and steps employed in this research are shown in Figure 2.

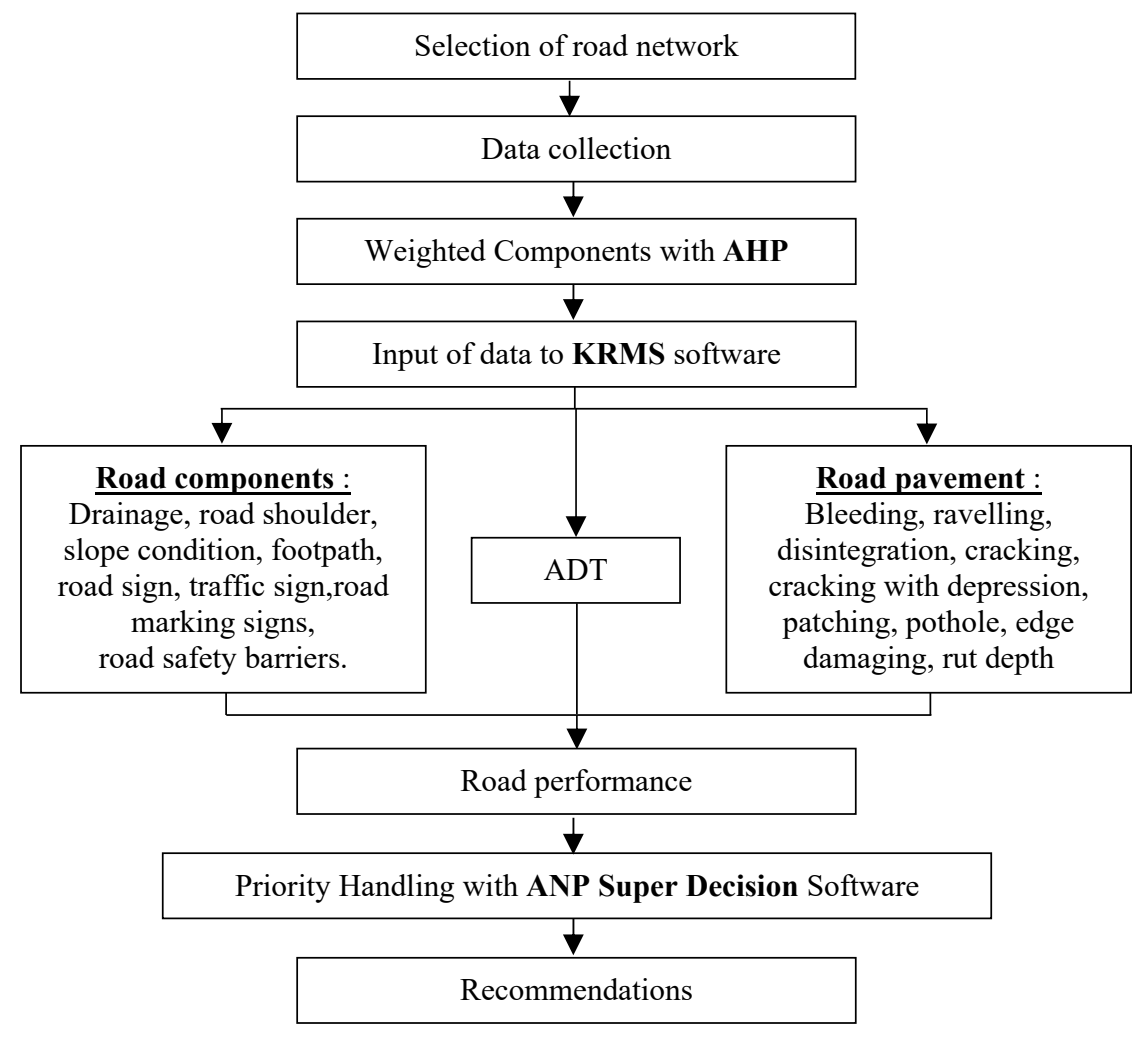

Fig. 2. Research method.

In this research, KRMS method was used to determine road performance without using the IRI value. Using this method, damage assessment of pavement and road components was done with the user-friendly KRMS software which provided in-depth results on SLD Reports (Straight Line Diagram) and Map Report Diagram (Strip Map Diagram). Determination of weight of road components like its physical and functional conditions was done using a questionnaire which was afterwards analysed using the Analytical Hierarchy Process (AHP) method. Determination of priority scale in handling Magetan district road was subsequently done using ANP (Analysis Network Process) with the help of Super Decision software. The data input method and criteria were then used to inform key priorities of the road.

\section{The outcome of analysis and reviews}

\subsection{Evaluation of the physical state of the road}

Table 2 indicates the magnitude of disfigurement per 100 meters for each part of the road. Table 2 is accompanied by a visual examination of the deterioration of the road as well. 
Table 2. Summary of road damages recorded for every segment of the road $\left(\mathrm{m}^{2}\right)$.

\begin{tabular}{|l|c|c|c|c|c|c|c|c|c|}
\hline \multicolumn{1}{|c|}{$\begin{array}{c}\text { Name of Road } \\
\text { Section }\end{array}$} & $\begin{array}{c}\text { Bleed- } \\
\text { ing } \\
\left(\mathbf{m}^{2}\right)\end{array}$ & $\begin{array}{c}\text { Ravell- } \\
\left.\text { ing } \mathbf{( m}^{2}\right)\end{array}$ & $\begin{array}{c}\text { Diste- } \\
\text { tion } \\
\left(\mathbf{m}^{2}\right)\end{array}$ & $\begin{array}{c}\text { Crack } \\
\text { with Depres- } \\
\left.\mathbf{s i o n} \mathbf{( m}^{2}\right)\end{array}$ & $\begin{array}{c}\text { Patching } \\
\left(\mathbf{m}^{2}\right)\end{array}$ & $\begin{array}{c}\text { Crack- } \\
\text { ing }\left(\mathbf{m}^{2}\right)\end{array}$ & $\begin{array}{c}\text { Pothole } \\
\left(\mathbf{m}^{2}\right)\end{array}$ & $\begin{array}{c}\text { Rutting } \\
\left(\mathbf{m}^{2}\right)\end{array}$ & $\begin{array}{c}\text { Edge } \\
\text { Damage } \\
\left(\mathbf{m}^{2}\right)\end{array}$ \\
\hline Takeran-Madigondo & - & 137,5 & 30,0 & 57,0 & 80,4 & 39,0 & 60,3 & - & - \\
\hline Maospati-Karangsono & - & - & - & 3,7 & 146,4 & 19,2 & 6,9 & - & 6,6 \\
\hline Tebon-Karangmojo & - & - & - & - & - & 9,0 & 11,3 & - & 8,0 \\
\hline Tebon-Batur & 0,4 & 0,3 & - & 0,7 & 377,2 & 106,9 & 2,1 & - & 5,2 \\
\hline $\begin{array}{l}\text { Tamanarum- } \\
\text { Lembeyan }\end{array}$ & 50,0 & 350,8 & 65,4 & - & $1.123,2$ & 108,6 & 10,9 & - & 6,6 \\
\hline Genengan-Lembeyan & 35,3 & 364,9 & 445,0 & 11,8 & $1.091,9$ & 126,2 & 13,7 & 134,1 & 22,1 \\
\hline Purwodadi-Grabahan & - & 70,5 & - & - & 86,2 & - & 9,1 & - & - \\
\hline Karangsono-Teguhan & 36,0 & 2,1 & 162,8 & - & 177,7 & 71,9 & 41,1 & - & 36,7 \\
\hline Parang-Turus & - & 10,0 & 28,5 & - & $1.471,6$ & 32,6 & 35,5 & - & 4,9 \\
\hline Pupus-Tapen & - & 7,1 & 41,1 & 11,1 & 126,9 & 79,3 & 32,5 & - & 4,6 \\
\hline $\begin{array}{l}\text { Takeran- } \\
\text { Kenongomulyo }\end{array}$ & - & - & - & - & 6,0 & - & - & - & - \\
\hline Tinap-Jongke & 73,1 & - & 1,6 & 1,6 & 167,7 & 8,8 & 25,8 & - & 0,9 \\
\hline Panekan-Jabung & - & - & - & - & 376,1 & 62,0 & 2,5 & - & - \\
\hline $\begin{array}{l}\text { Tulung- } \\
\text { Kenongomulyo }\end{array}$ & - & - & - & - & 28,1 & 92,4 & 3,1 & - & 0,6 \\
\hline Ringinagung-Bangsri & - & 0,5 & - & - & 2,0 & - & 6,2 & - & - \\
\hline Pupus-Semen & - & 4,0 & 92,2 & 4,5 & - & 163,10 & 141,8 & - & 8,0 \\
\hline
\end{tabular}

An analysis of Table 2 shows that patches, loose and cracked grains (in that order) remain the highest form of road degeneration. $5261.4 \mathrm{~m} 2$ is the sum of road damage due to patches while that caused by grain loosening is $947.17 \mathrm{~m} 2$. However, $919 \mathrm{~m} 2$ is recorded for crack degenerations.

\subsection{Ascertainment of weight requirements of road components}

Using the Analytical Hierarchy Process (AHP) technique via a questionnaire, an analysis of the ascertainment of the weight requirement of road components which covers the utility and physical state of roads can be carried out. Post analysis via the AHP technique resulted in the determination of the mass of each road component. These are - Road on Pavement Components 80\%, Components off Pavement Road 20\%, Physical Condition on Pavement 73\%, Condition on Pavement Function 27\%, and Condition off Pavement Function 81\%. Others are: Physical Conditions off Pavement $19 \%$, road shoulder 36\%, Drainage Edge 24\%, Edge Slope 19\%, Sidewalk 12\%, Street Fixtures 8\%, Rut depth/mild erosion 25\%, and Rut depth/severe erosion 30\%. The following was also observed: Higher than on pavement $24 \%$, Lower than on pavement $11 \%$, concrete rebate required 9\%, Clogged drain 43\%, Eroded drain 23\%, Collapsed drain $24 \%$, Needing to attach stones $10 \%$, Road Sign $41 \%$, road safety barrier $26 \%$, road marking signs $18 \%$, and road marking $14 \%$. 


\subsection{Model making of priority for road handling}

Figure 3 is the representation of the priority scale model adopted in this study. Nevertheless, the nexus between criteria on priority and alternatives is derived from the priority scale determination approach.

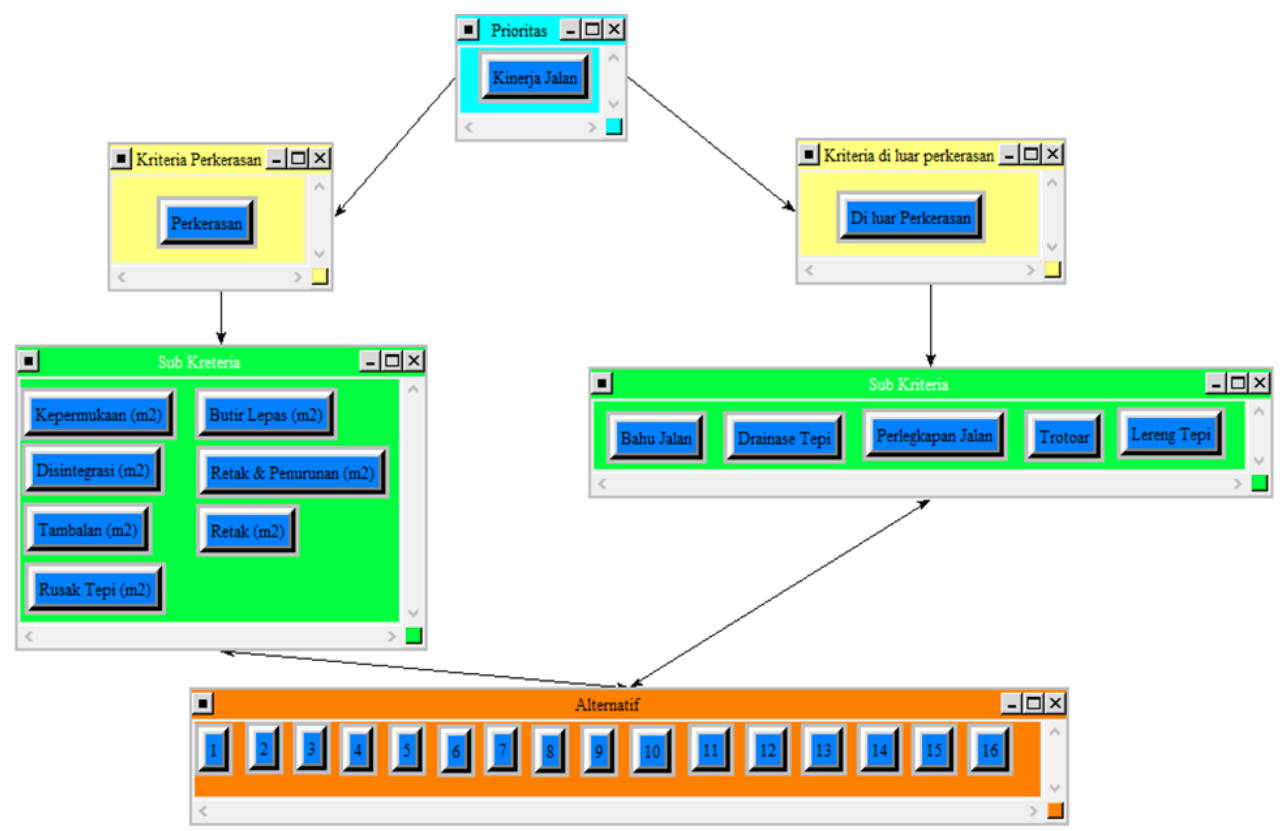

Fig. 3 Priority Scale Determination Model on Super Decision Software.

Using the Analysis Network Process (ANP) alongside the Super Decision software, the priority of damage handling led to the determination of the first priority road section of Genengan-Lembeyan road. That of Tamanarum-Lembeyan road came second while Karangsono-Teguhan came third in the handling priority.

\subsection{Road performance evaluation}
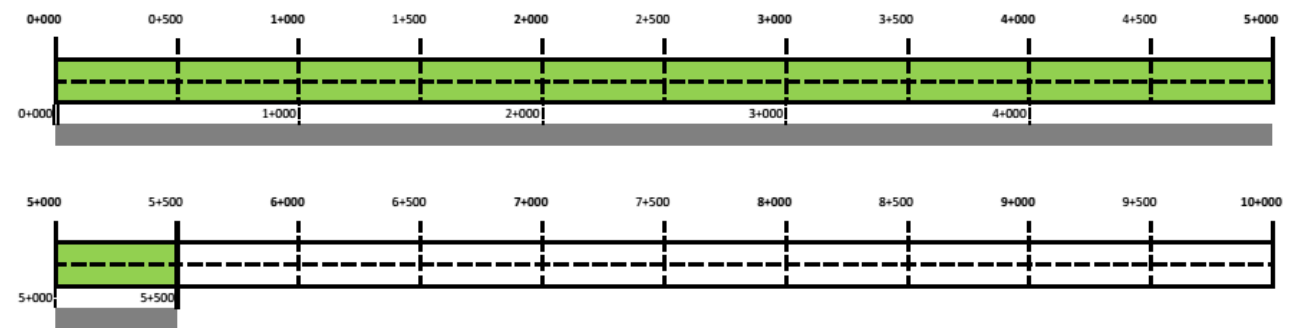

Keterangan

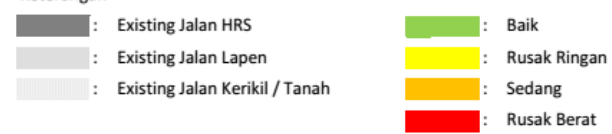

Fig. 4. Straight Line Diagram of Takeran-Mardigondo Road Segment 
The all-green color in the diagram above shows that the present HRS on the TakeranMardigondo road is in an excellent state.
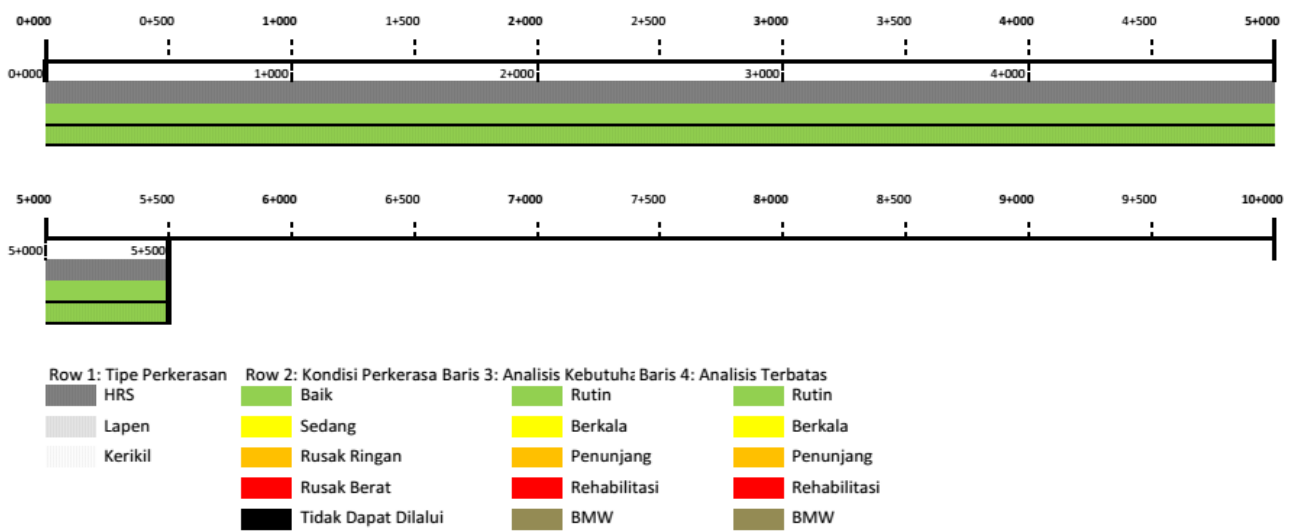

Fig. 5. Strip Map Diagram on Takeran-Mardigondo Road Segment

The Takeran-Mardigondo road demands periodic maintenance because the state of its present HRS is positive. The diagram above is self-explanatory.

\subsection{Road maintenance handling: suggestions}

A recap of our submissions regarding the maintenance handling of the length and breadth of the district road are found in Table 3.

Table 3. Performance-based District Road Maintenance Handling Recommendations

\begin{tabular}{|c|l|c|l|}
\hline No. & Name of Road Section & Performance & $\begin{array}{c}\text { Maintenance } \\
\text { Recommendations }\end{array}$ \\
\hline 1. & Takeran-Mardigondo & Good & Routine maintenance \\
\hline 2. & Maospati-Karangsono & Good & Routine maintenance \\
\hline 3. & Tebon-Karangmojo & Good & Routine maintenance \\
\hline 4. & Tebon-Batur & Good & Routine maintenance \\
\hline 5. & Karangsono-Teguhan & Good & Routine maintenance \\
\hline 6. & Purwodadi-Grabahan & Good & Routine maintenance \\
\hline 7. & Genengan-Lembeyan & Good & Routine maintenance \\
\hline 8. & Tamanarum-Lembeyan & Good & Routine maintenance \\
\hline 9. & Parang-Turus & Good & Routine maintenance \\
\hline 10. & Ringinagung-Bangsri & Good & Routine maintenance \\
\hline 11. & Tulung-Kenongomulya & Good & Routine maintenance \\
\hline 12. & Panekan-Jabung & Good & Routine maintenance \\
\hline 13. & Tinap-Jongke & Good & Routine maintenance \\
\hline 14. & Takeran-Kenongomulya & Good & Routine maintenance \\
\hline 15. & Pupus-Tapen & Good & Routine maintenance \\
\hline 16. & Pupus-Semen & Good & Routine maintenance \\
\hline
\end{tabular}




\section{Conclusion}

As determined by the outcome of the analysis, we arrive at the following conclusions :

a. The physical evaluation of roads using the KRMS software is supported by the findings in 16 Straight Line Diagram. It indicates that the state of 16 district road of Magetan Regency is in excellent shape.

b. The basis of the analysis embraced the entire range of district road deteriorations determined by visual inspection of the road. We recommend that routine maintenance of all road segments covered in the Magetan district should be carried out. Our suggestion flows from an evaluation of the road using KRMS software and the outcome of 16 Strip Map Diagrams. Also, the first priority road segment handling is Genengan-Lembeyan road followed by that of Tamanarum-Lembeyan road and Karangsono-Teguhan. This would not have been possible without the priority of damage handling analysis of the Analysis Network Process (ANP) technique and the Super Decision software.

\section{Recommendations}

We suggest that future studies should be very extensive and employ values such as SDI, PCI, and IRI. Alternatively, the Bina Marga technique, as well as AASHTO 1993 can be used side by side with the earlier values. By so doing, we can accurately determine the district road performance, and that would lead to excellent road handling.

\section{References}

1. Suwardo, Sugiharto, Tingkat Kerataan Jalan (PSI dan RCI), Simposium VII FSTPT UKP, (2004)

2. Suherman, Persamaan Korelasi, Jurnal Teknik Sipil, VIII (3), 206-214 (2008)

3. D.A. Siahaan, M.S. Surbakti, Analisis Perbandingan Nilai IRI, (FT USU, 2012)

4. G. Jannat, X.X. Yuan, M. Shehata, Development of Regression Equations, International Journal of Pavement Engineering, (2014)

5. Y. Shah, S. Jain, D. Tiwari, M. Jain, Development of Overall Pavement Condition Index, Procedia-Social and Behavioral Sciences, 104, 332-341 (2013)

6. Suryoto, D.P. Siswoyo, A. Setyawan, The Evaluation of Fungtional Performance, Procedia Engineering, 171, 1432-1442 (2017)

7. U. Tho'atin, A. Setyawan, M. Suprapto, Penggunaan Metode IRI, SDI, PCI, Seminar Nasional Sains dan Teknologi, FT UMJ, (2016)

8. M.Y.M. Putra, B.S. Subagio, E.S. Hariadi, S. Hendarto, Evaluasi Kondisi Fungsional dan Struktural, Jurnal Teknik Sipil, XX (3), 245-254 (2013)

9. Japan International Cooperation Agency, Teknik Pengelolaan Jalan, (Pusat Penelitian Pengembangan Prasarana Transportasi, 2005) 